EXPERIMENTAL STUDY

\title{
Development of an experimental ovarian tumor: immunocytochemical analysis
}

\author{
E Sorianello ${ }^{1,2}$, S Fritz ${ }^{3}$, C Beyer ${ }^{5}$, D B Hales ${ }^{4}$, A Mayerhofer $^{3}$, C Libertun ${ }^{1,2}$ and V Lux-Lantos ${ }^{1}$ \\ ${ }^{1}$ Instituto de Biología y Medicina Experimental and ${ }^{2}$ Department of Physiology, University of Buenos Aires Medical School, Buenos Aires, Argentina, \\ ${ }^{3}$ Anatomisches Institut, Universität München, München, Germany, ${ }^{4}$ Department of Physiology and Biophysics, University of Illinois at Chicago, \\ Chicago, Illinois, USA and ${ }^{5}$ Anatomie und Zellbiologie, Universität Ulm, Ulm, Germany
}

(Correspondence should be addressed to C Libertun, Laboratorio de Neuroendocrinología, Instituto de Biología y Medicina Experimental, V Obligado 2490, 1428 Buenos Aires, Argentina; Email: libertun@dna.uba.ar)

\begin{abstract}
Objective: The aim of the present work was to study whether immunocytochemical parameters present in the normal ovary were altered after tumor development under high gonadotropin levels.

Methods: Ovarian tumors (luteoma): castrated female rats had an ovary grafted into the spleen; tumors were left to develop for 1, 2, 3 or 7 months. The presence of apoptotic cells (TUNEL method) and the expression of proliferating cell nuclear antigen (PCNA), gap junction protein $(\mathrm{Cx} 43)$, steroidogenic acute regulatory protein (StAR), aromatase and synaptosome-associated protein of $25 \mathrm{kDa}$ (SNAP-25) were determined by immunocytochemistry. Some of these findings were confirmed by RT-PCR (Cx43, StAR, SNAP-25). Inhibin subunit mRNAs were investigated by Northern blot.

Results: PCNA staining of tumors was mainly found in granulosa cells of transforming follicles and was absent from luteinized follicles. A nearly complete absence of apoptosis was observed. Cx43 was mainly found in follicles, while it was very weakly expressed or absent in luteinized follicles. StAR protein expression, indicating active steroidogenesis, was demonstrated only in luteinized follicles and in thecal cells, but was absent from granulosa cells. Aromatase immunoreactivity was very intense in granulosa and also present in luteal cells. Membrane-associated and cytoplasmic SNAP-25 immunostaining was determined in patches of endocrine cells in the follicles, as well as in the luteinized follicles. The expression of mRNAs for Cx43, StAR and SNAP-25 (RT-PCR) and inhibin subunits (Northern blots) were confirmed in 1-, 3- and 7-month-old tumors.

Conclusions: These results indicated that luteoma most likely develop from unruptured follicles by hypertrophy and proliferation of follicular cells. Circulating gonadotropins seem to play a fundamental role in maintaining the expression of proteins typically expressed in normal ovary, while avoiding apoptosis in this tissue.
\end{abstract}

European Journal of Endocrinology 147 387-395

\section{Introduction}

An ovary implanted into the spleen of an ovariectomized rat develops into a tumor, growing in response to gonadotropins. Luteinizing hormone (LH) and follicle-stimulating hormone (FSH) levels are high in these animals as the steroids secreted by the tumor are poured into the hepatic-portal vein and are consequently metabolized by the liver before reaching the general circulation $(1,2)$. In this way the negative feedback, which is normally exerted at the hypothalamic and hypophyseal levels, is abolished. This tumor grows and acquires approximately three times the initial volume of the grafted estrous ovary after 2 months (3) and 20 times after 1 year of development (4). We have demonstrated that this tumor depends on gonadotropins for its growth by treating tumorbearing rats with buserelin, a gonadotropin-releasing hormone (GnRH) agonist that downregulates $\mathrm{LH}$ and FSH secretion; this resulted in very significant tumor regression (3). A direct action of GnRH analogs on the tumor has also been demonstrated $(5,6)$. In women, the risk of suffering ovarian cancer has been related to gonadotropin levels. High levels of gonadotropins in the early postmenopause have been suggested to play a role in the development of ovarian neoplasms. This is supported by the dramatically increased incidence of ovarian cancer in women above the age of 45 years, when gonadotropins reach high levels $(7,8)$. Therefore, the dependency on gonadotropins for growth in this experimental ovarian tumor is similar to the one proposed for different 
ovarian pathologies such as certain ovarian carcinomas $(9,10)$, granulosa cell tumors after ovarian stimulation in treatments of infertility (11) or in the polycystic ovary syndrome (12), rendering this tumor an interesting model for the study of tumor development under hypergonadotropinemia.

This experimental ovarian tumor is highly luteinized (luteoma) (4) and hormonally active since it secretes estradiol, progesterone and inhibins $(4,5)$. Inhibins have been proposed as markers of ovarian tumors $(13,14)$.

The aim of the present study was to further characterize this experimental ovarian tumor by determining different immunocytochemical parameters described in normal ovary (15-20), to evaluate if it was maintained or modified during tumor development under high gonadotropin levels.

For this purpose, the expression of proliferating cell nuclear antigen (PCNA) and the presence of apoptotic cells by the TUNEL method were investigated. In addition, parameters related to tumor secretion capacity, such as the expression of steroidogenic acute regulatory protein (StAR), a key protein involved in steroid biosynthesis, aromatase, the enzyme which converts androgens into estrogens, the synaptosomeassociated protein of $25 \mathrm{kDa}$ (SNAP-25), this last one being involved in exocytotic processes, and connexin 43 (Cx43), which participates in ovarian cell interaction, were also determined. Where possible, these findings ( $\mathrm{Cx} 43$, StAR, SNAP-25) were confirmed by RT-PCR in 1-, 3- and 7-month-old tumors. The expression of inhibin subunit mRNAs was analyzed by Northern blot in these tumors at the same stages of development.

\section{Materials and methods}

\section{Animals}

Adult female virgin Sprague-Dawley rats (200-250 g) from the Instituto de Biología y Medicina Experimental colony were housed in groups in an air-conditioned room, with lights on from 0700 to $1900 \mathrm{~h}$. They were given free access to laboratory chow and tap water. At the end of experimental procedures, animals were killed by decapitation according to protocols for animal use approved by the institutional animal care and use committee (IBYME-CONICET) which follows NIH guidelines. Animals were cycled daily and, after two regular cycles, they were operated on during the morning of estrus. Surgical procedures were performed as previously described (2). Briefly, animals were anesthetized with ketamine $(100 \mathrm{mg} / \mathrm{kg}$ body weight i.p.), both ovaries were removed and one gonad was cleared of the adherent fat and oviduct and was inserted into the spleen. Tumors were left to develop for $1,2,3$ or 7 months. Thereafter, animals were decapitated and the tumors were either embedded in paraffin for immunocytochemical analysis or completely cleared from adherent tissue and homogeneized in TRIZOL (Gibco-BRL, Rockville, MD, USA) for RNA extraction.

\section{Immunocytochemistry}

Tissue sections were deparaffinized and hydrated as described by Fritz et al. (18). The cellular distribution of PCNA, Cx43 and SNAP-25 in the tumors was determined by immunohistochemistry, using commercially available monoclonal or polyclonal antisera: antiPCNA (1:100) (Calbiochem, Bad Soden, Germany), anti SNAP-25 (1:500) (Sternberger monoclonals Inc., Baltimore, MD, USA) and anti rat-Cx43 (1:500) (Sigma, Deisenhofen, Germany) (16). In addition, a well-characterized StAR antibody (1:1000) (19) and an aromatase antiserum (1:500-1:2000) (21) were used. Immunohistochemical procedures using the avidin-biotin method were employed as described previously (18). Immunoreactivity was visualized with diaminobenzide. For control purposes, the first antiserum/antibody was omitted and incubations with normal rabbit serum/mouse serum were carried out instead. Sections were examined with a Zeiss Axiovert microscope.

For detection of apoptotic cells, the In Situ Cell Death Detection Kit (Boehringer Mannheim, Mannheim, Germany) was employed and procedures were followed as indicated in the manufacturer's instructions.

The complete sets of immunocytochemical experiments were performed on five different 1- or 2month-old tumors.

\section{RT-PCR analyses and sequencing}

Total RNA was prepared from 1-, 3- and 7-month-old tumors by the Chomczynski \& Sacchi method (22) which utilizes the TRIZOL reagent. Normal 3-monthold rat ovary and normal rat spleen were used as controls. Total RNA (100-500 ng) were used for reverse transcription utilizing an 18-mer polydeoxythymidine primer and Moloney's murine leukemia virus reverse transcriptase (Promega, Mannheim, Germany). Amplification of $\mathrm{Cx} 43$, StAR and SNAP-25 was performed as described $(16-19,23)$. In order to be able to compare RT-PCR reactions of different animals, only those RNA samples were used which, after RT and PCR using tubulin primers, yielded comparable bands. PCR amplification consisted of $30-35$ cycles of denaturing $\left(94^{\circ} \mathrm{C}\right.$, $15 \mathrm{~s})$, annealing $\left(55^{\circ} \mathrm{C}, 1 \mathrm{~min}\right)$ and extension $\left(72^{\circ} \mathrm{C}\right.$, $2 \mathrm{~min})$. The PCR reaction products were separated on $2 \%$ agarose gels and visualized with ethidium bromide. They were verified by sequencing, as described (16-19, 23).

Oligonucleotide primers used for amplification of rat Cx43, $\alpha$-tubulin, rat StAR and rat SNAP-25 were synthesized according to the published GenBank 
sequences, namely $\mathrm{Cx} 43$ GenBank (accession number X06656); sense: 5'-GCGGCGGCTTCACTTTCATTA-3' corresponding to nt 158-179; antisense 5'-CAGACGTTTTCGCAGCCAGGTTG-3' complementary to nt 371-395; tubulin (accession number K 00558); sense: 5'-CACCCGTCTTCAGGGCTTCTTGGTTT-3' corresponding to nt 398-415; antisense: 5'-CATTTCACCATCTGGTTGGCTGGCTC-3' complementary to $\mathrm{nt}$ 779-796; StAR (accession number RNU76419); sense: 5'-TGGAGAGGCTCTATGAAGAGC-3' corresponding to nt 987-1004; antisense: 5'-GCCACGTAAGTTTGGTCTTAG-3' complementary to nt 1214-1233; primer design in comparison with Ronen-Fuhrmann et al. (24); SNAP-25 (accession number AB003991); sense: 5'-ATGGCCGAGGACGCAGACATGCGTAAT-3' corresponding to nt 1-27; antisense: 5'-AGCATCACTGGATTTAAG-3' complementary to nt 283-300.

\section{Northern blot determination of inhibin subunit mRNAs}

Total RNA from 1-, 3- or 7-month-old tumors and estrous ovaries (four to five samples per group) was extracted, as described above. Northern blots were performed as described by Woodruff et al. (25). Briefly, $20 \mu \mathrm{g}$ total RNA, previously verified for integrity, was subjected to horizontal electrophoresis in denaturing agarose-formaldehyde gels and transferred to nylon membranes (Hybond-N; Amersham Life Science, Little Chalfont, Bucks, UK). Membranes were exposed overnight at $65^{\circ} \mathrm{C}$ to heat-denaturalized probes for $\alpha, \beta A$, $\beta B$ inhibin subunits (generously provided by $\mathrm{Dr}$ Aaron Hsueh) or glyceraldehyde 3-phosphate dehydrogenase $(\mathrm{G} 3 \mathrm{PDH})$ as an internal control, labeled with ${ }^{32} \mathrm{P}$ (Random Primed DNA Labeling Kit; Boehringer Mannheim). Membranes were then exposed to X-ray films (Biomax MS; Eastman Kodak Company, Rochester, NY, USA). Molecular sizes were estimated with RNA molecular weight standards (Promega).

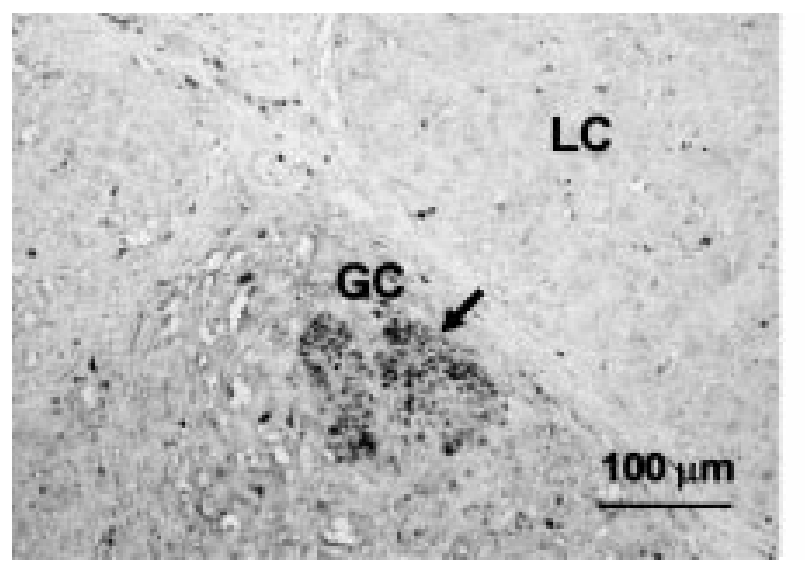

\section{Results}

\section{Tumor development}

Cell proliferation, detected by an antibody recognizing PCNA, was mainly found in transforming follicles and was absent from luteinized follicles (Fig. 1). A major difference from normal ovaries was the almost complete absence of apopotic cells after 1-2 months of tumor development, as determined by the TUNEL method (Fig. 2).

A prominent feature indicating local interaction of ovarian cells, namely the presence of gap junctions consisting of $\mathrm{Cx} 43$, was also demonstrated in tumor samples (Fig. 3). Interestingly, $\mathrm{Cx} 43$ was mainly found in follicles (granulosa cells) but not in luteinized follicles, which thus differs from active corpora lutea in the normal ovary (15).

\section{Tumor secretion capacity}

A immunocytochemical analysis of hormone production capacity of 1-month-old tumors was undertaken by determining the presence of key enzymes and factors involved in hormone synthesis or secretion. Active steroidogenesis is indicated by high StAR protein expression. StAR was demonstrated only in luteinized follicles and in thecal cells, but was absent from granulosa cells of follicles, indicating that the latter do not participate in de novo steroid production (Fig. 4).

Aromatase, the enzyme which coverts androgens into estrogens, was very intense in granulosa cells and also present in luteal cells (Fig. 5), in agreement with high estradiol output by tumor cells (5).

SNAP-25, which is a marker for exocytotic processes, was found in patches of endocrine cells in the follicles, as well as in luteinized follicles (Fig. 6, left). In line with previous observations (17), membrane-associated and cytoplasmic staining was observed. Neither SNAP-25 nor tyrosine-hydroxylase (TH)-immunoreactive nerve

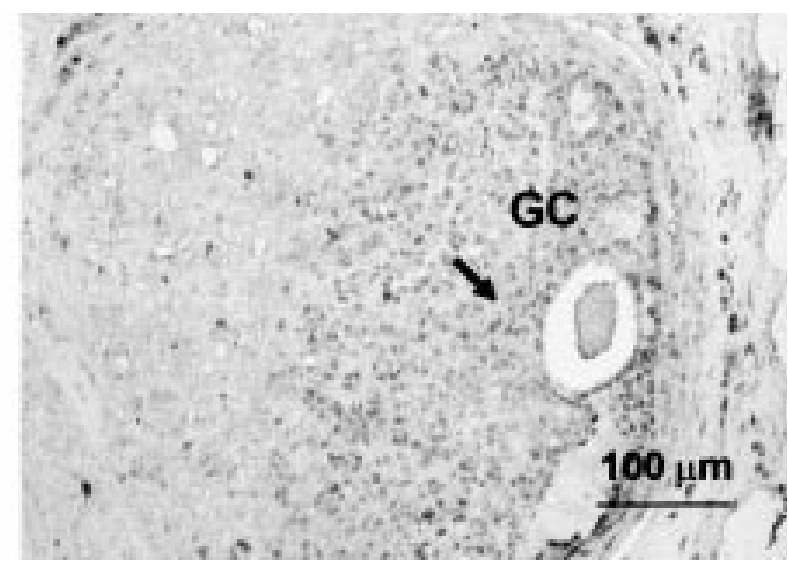

Figure 1 PCNA immunoreactivity in 1-month-old luteoma samples. Anti-PCNA antibody was diluted 1:100. Immunostaining was observed mainly in granulosa cells. Arrows indicate positive anti-PCNA staining. GC: granulosa cells and LC: luteal cells. 

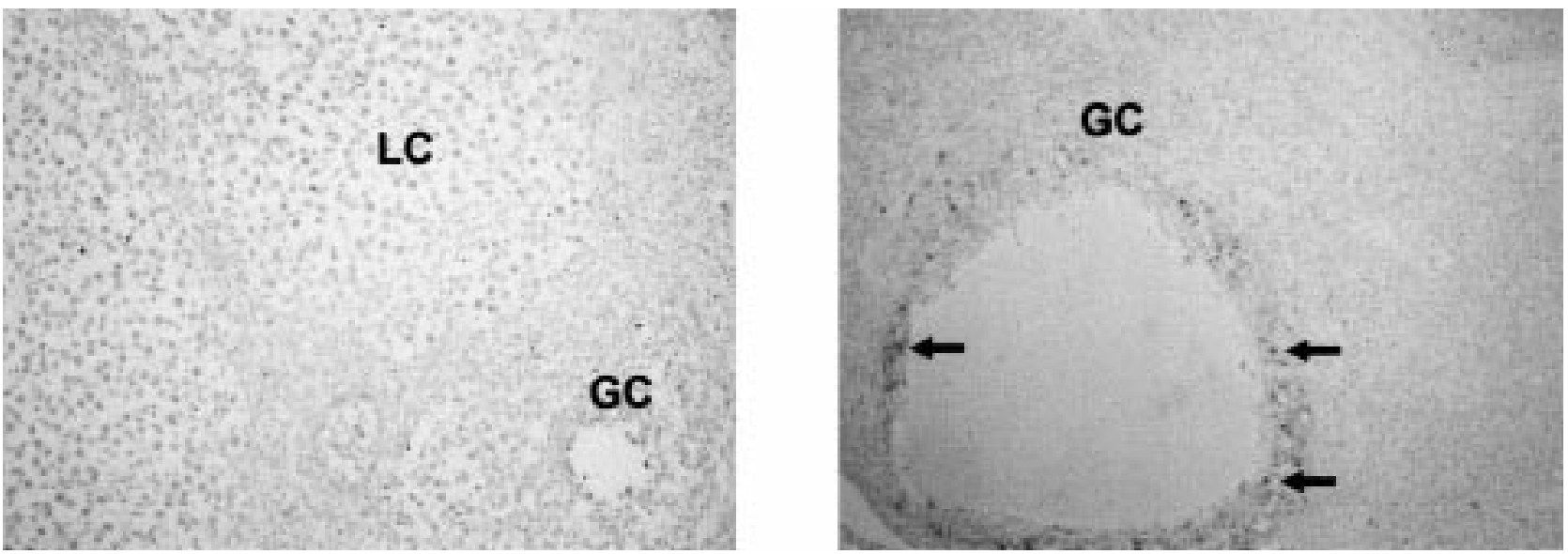

Figure 2 Apoptotic cell staining by the TUNEL method in 1-month-old luteoma sections (left panel). Note the absence of staining in luteoma cells when compared with a control ovary section (right panel, positive cells in large antral follicle indicated by arrows). GC: granulosa cells and LC: luteal cells.

fibers were found in the transplants, but were present in the spleen (TH staining not shown) (Fig. 6, right).

A summary of the expression of the ovarian markers in the different cell types of the experimental ovarian tumors is shown in Table 1.

\section{RT-PCR and Northern blot analyses}

RT-PCR analysis confirmed the presence of mRNA for rat (r) $\mathrm{Cx} 43$, rStAR and rSNAP-25 in 1- and 3-monthold luteoma, indicating that they are present in the tumors at different stages of development and when a high degree of luteinization has taken place (Fig. 7). Furthermore, rCx43, rStAR and rSNAP-25 expression were also present in 7-month-old tumors (not shown).

Expression of mRNA for inhibin subunits $\alpha(1.4 \mathrm{~kb})$, $\beta \mathrm{A}(5.8$ and $3.2 \mathrm{~kb})$ and $\beta \mathrm{B}(3.5 \mathrm{~kb})$ was detected by Northern blot in 1-, 3- and 7-month-old tumors. The
Table 1 Immunocytochemical expression of ovarian markers in experimental ovarian tumors.

\begin{tabular}{lccc}
\hline Ovarian marker & Granulosa cells & Luteal cells & Thecal cells \\
\hline PCNA & ++ & - & - \\
Cx43 & ++ & - & - \\
StAR & - & ++ & + \\
Aromatase & +++ & + & - \\
SNAP-25 & + & + & - \\
\hline
\end{tabular}

G3PDH mRNA (1.2 kb), expressed constitutively, was used as an internal control (Fig. 8). Characteristic patterns of expression were evident for each of the inhibin subunits; while $\alpha$ expression remained fairly constant during tumor development, $\beta \mathrm{A}$ and $\beta \mathrm{B}$ were highly expressed at 1 month of development and decreased to nearly undetectable levels at 3 months of development.
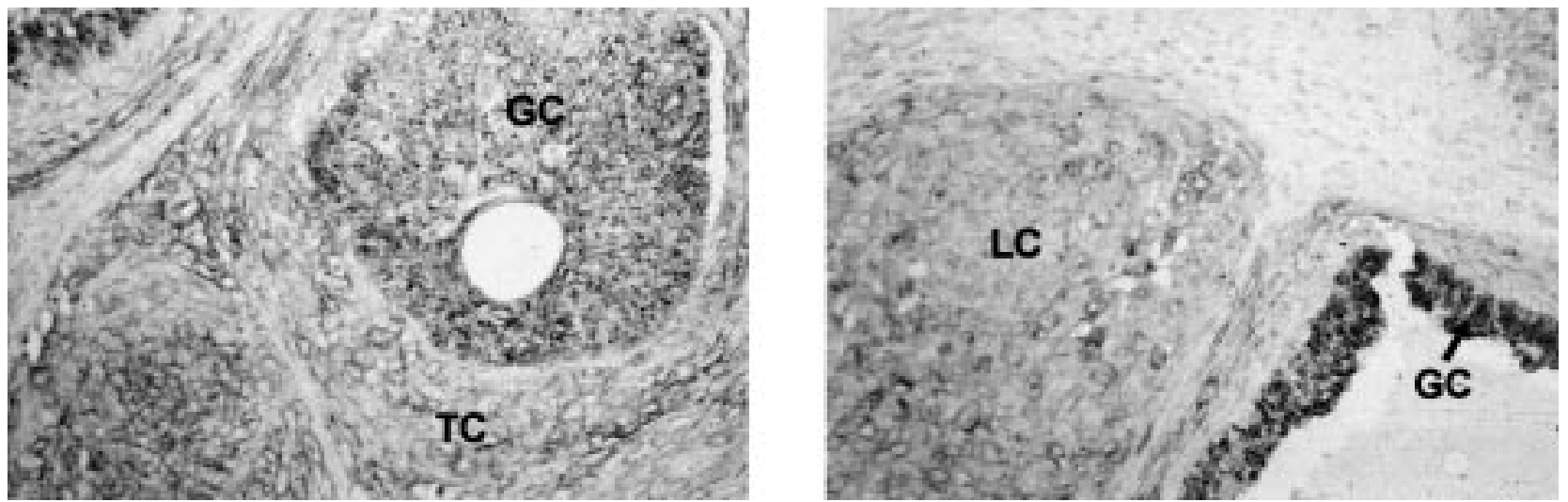

Figure 3 Cx43 immunoreactivity is demonstrated in 1-month-old luteoma sections using a specific Cx43-antiserum (1:500). Note positive staining mainly in granulosa cells (arrow). GC: granulosa cells, LC: luteal cells and TC: thecal cells. 


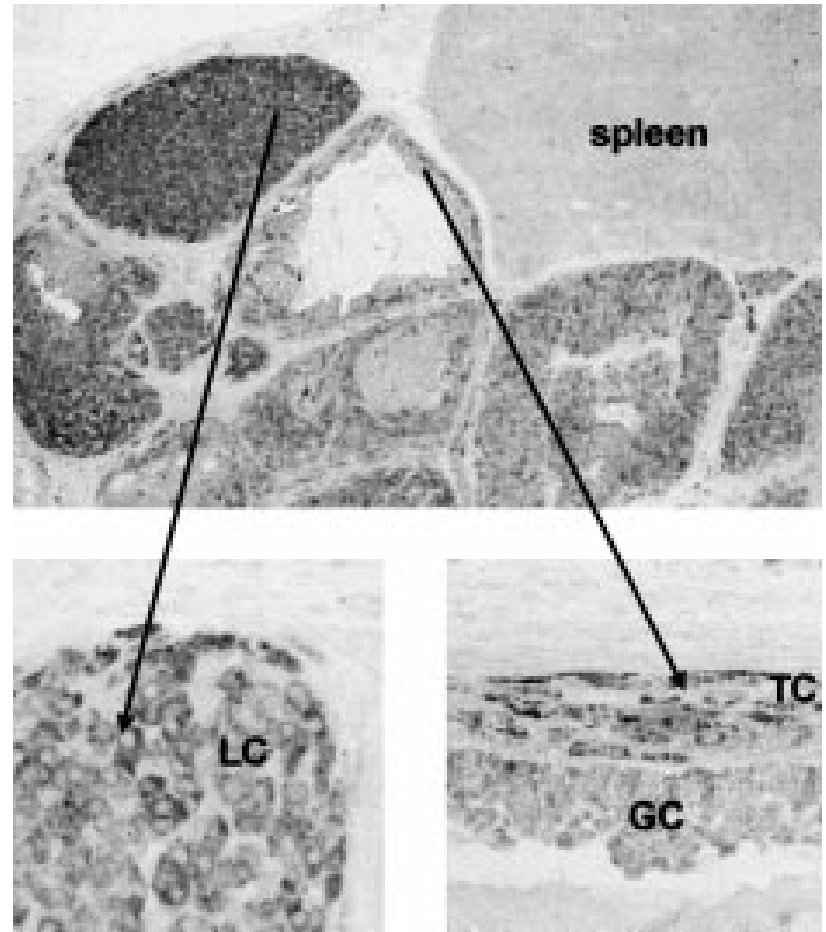

Figure 4 StAR protein immunostaining in 1-month-old tumor sections (antibody 1:1000). Positive staining was demonstrated only in luteinized follicles and in thecal cells, but was absent from granulosa cells of follicles. GC: granulosa cells, LC: luteal cells and TC: thecal cells.

\section{Discussion}

The aim of the present study was to further characterize this experimental intrasplenic ovarian tumor by determining various immunocytochemical parameters described in the normal ovary, in order to establish if these suffered any modification during tumor development under constant gonadotropin hyperstimulation.

Effective growth of a certain tissue is the result of the balance between proliferation and cell death. Both parameters were examined in these intrasplenic ovarian tumors. Cell proliferation (PCNA-positive cells) was mainly found in the granulosa cells of transforming follicles and was absent from luteinized follicles, in agreement with data in the literature (26). These data suggest that luteoma tumors most likely develop from unruptured follicles by hypertrophy and proliferation of follicular cells, under the influence of high gonadotropins present in luteoma-bearing animals, in agreement with data in the literature for growing follicles $(27,28)$, although the participation of other proliferating agents (29-31) secreted by this tumor $(5,32)$ cannot be discarded. The low index of proliferating cells in luteoma tissue is in agreement with the benign characteristics of this tumor (4), as high PCNA indexes in ovarian tumors have been related to malignancy and poor prognosis (33). Apoptosis, on the other hand, is a normal cellular process involved in various events of cell turnover in the ovary, such as follicle atresia or corpus luteum demise (34). In the luteoma, a major difference with regard to normal ovaries was the almost complete absence of apopotic cells after 1-2 months of tumor development, as determined by the TUNEL method. This observation suggested the hindrance of corpora lutea regression or of follicle atresia in this experimental luteoma, in which both corpora lutea and follicles in different stages of development and luteinization were observed. Both gonadotropins have been described as rescuing ovarian cells from apoptosis (34-36). Therefore, the high circulating gonadotropins present in luteoma-bearing animals may be responsible for the low apoptotic index observed. Together, these data on proliferation and
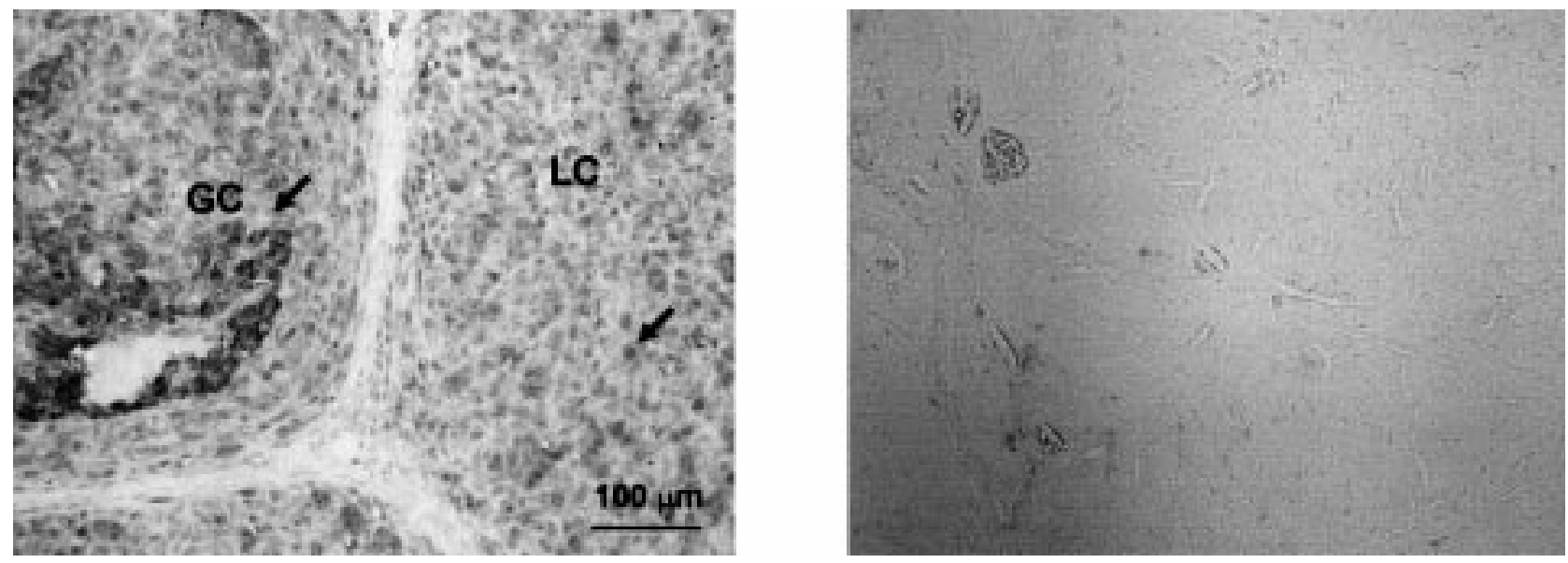

Figure 5 Aromatase immunoreactivity (antibody 1:500) in 1-month-old tumor sections was very intense in granulosa cells and also present in luteal cells (left panel). Note the total absence of staining when tissue was incubated without primary antibody (right panel). GC: granulosa cells and LC: luteal cells. 

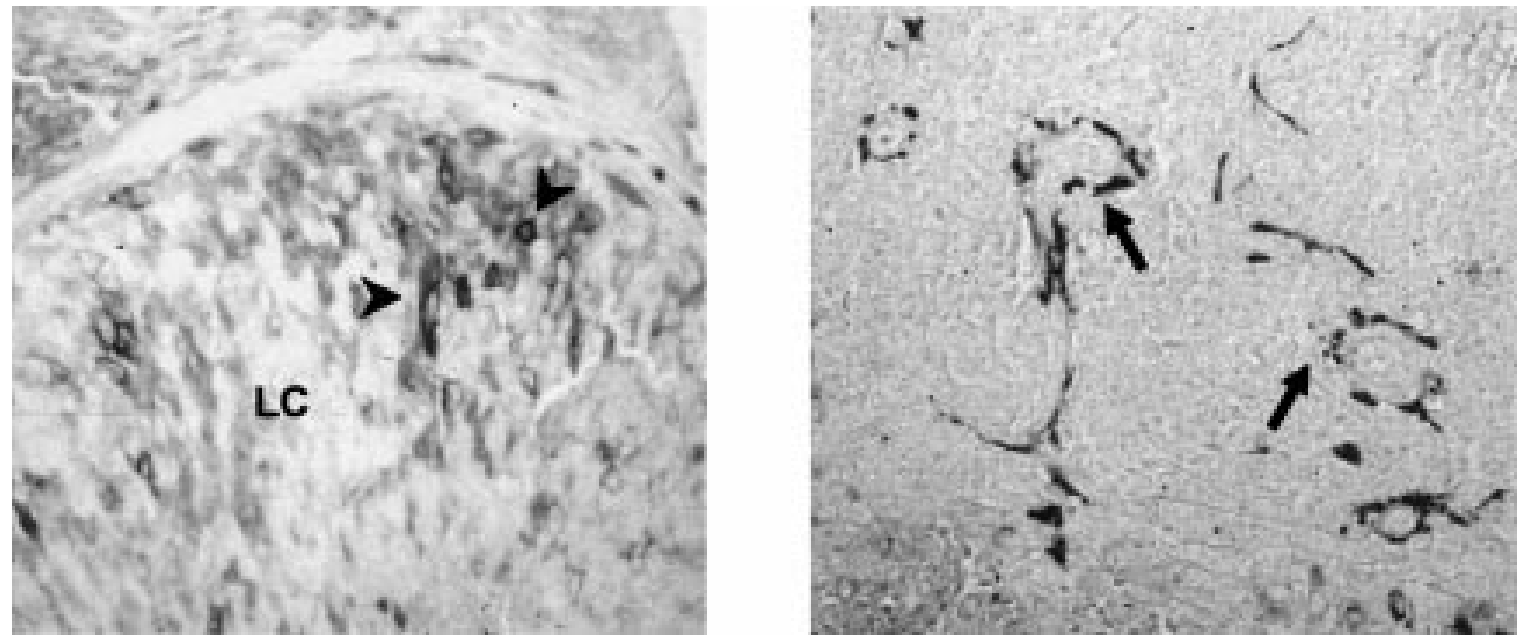

Figure 6 SNAP-25 immunoreactivity (antibody 1:500) in 1-month-old luteoma sections (left panel) and spleen sections (right panel). Membrane-associated and cytoplasmic staining was found in patches of endocrine cells in luteinized follicles (arrow heads), as well as in developing follicles (not shown). SNAP-25 immunoreactive nerve fibers were present in the spleen but absent from transplants (arrows). LC: luteal cells.

apoptosis suggest that the luteoma represents a highly differentiated non-metastatic tumor model, which most likely develops from unruptured follicles by hypertrophy and proliferation of granulosa cells and persistence of corpora lutea. In addition, our results do not support the idea that ovarian cancer can be solely attributed to high circulating gonadotropin levels, as has been suggested. Although gonadotropins may mediate ovarian hyperplasia and hypertrophia in the luteoma model, this input does not appear to induce malignant transformation of ovarian cells, at least in the period assessed in this study. This conclusion is supported by the work of Kumar et al. $(37,38)$ in transgenic

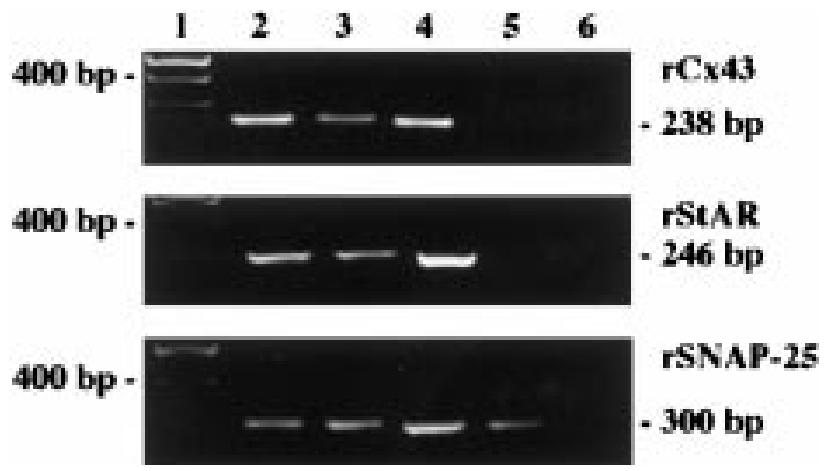

Figure 7 Expression of rCx43, rStAR and rSNAP-25 in luteoma cells by RT-PCR using specific primers synthesized according to the published GenBank sequences. (1) $100 \mathrm{bp}$ DNA ladder, (2) 1-month old luteoma, (3) 3-month-old luteoma, (4) normal 3month-old rat ovary, (5) normal rat spleen and (6) control PCR reaction, omission of template. Note the absence of $r C \times 43$ and rStAR expression in the spleen and the presence of SNAP-25 in agreement with immunocytochemistry results showing immunoreactive nerve fibers in the spleen. models, where they propose that gonadotropins are modifier factors for gonadal tumor development in inhibin-deficient mice.

A characteristic marker of ovarian cells is the expression of the protein $\mathrm{Cx} 43$ present in gap junctions. Gap junctions show a particular distribution pattern during follicle development and subsequent corpus luteum formation and demise $(15,39-41)$. It has been demonstrated that FSH increases levels of Cx43 mRNA and its phosphorylation, changes which are associated with reduced proliferation and enhanced differentiation $(16,42)$. On the other hand, LH induced, as an immediate response, the phosphorylation

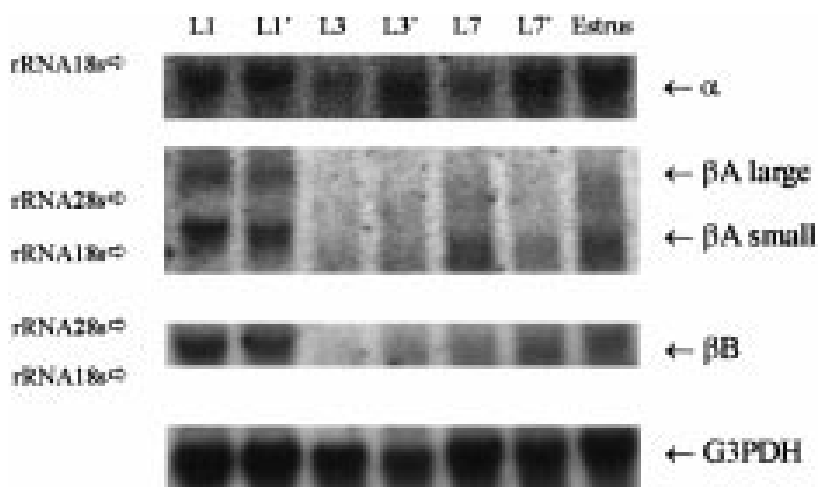

Figure 8 Expression of inhibin subunit mRNAs in 1-, 3- and 7-month-old luteoma by Northern blot (L1, L3 and L7 and L1', L3' and $L 7^{\prime}$ respectively; two independent luteomas in each case). Estrous ovaries were used as controls (Estrus). $\alpha$ (1.4 kb), $\beta A$ (large: $5.8 \mathrm{~kb}$ and small: $3.2 \mathrm{~kb})$ and $\beta \mathrm{B}(3.5 \mathrm{~kb})$ subunits were detected. The G3PDH mRNA (1.2 kb), expressed constitutively, was used as an internal control. Arrows on the left indicate the migration of $18 \mathrm{~S}$ and $28 \mathrm{~S}$ rRNAs. 
of $\mathrm{Cx} 43$ and, as a later response, the reduction of $\mathrm{Cx} 43$ protein concentration, because of attenuation of its gene expression (43). Interestingly, loss or dysfunction of gap junctions appears to be important in allowing cancer cells to escape growth regulation, as has been shown by the loss of $\mathrm{Cx} 43$ expression in human ovarian carcinoma cells (44). In consequence, $\mathrm{Cx} 43$ is an interesting factor to analyze in luteoma sections. In these tumors, $\mathrm{Cx} 43$ was mainly found in follicles (granulosa cells) but was very weakly expressed in or absent from luteinized follicles; this therefore differs from active corpora lutea in the normal ovary. The presence of $\mathrm{Cx} 43$ was confirmed by RT-PCR in 1-, 3- and 7month-old luteoma, indicating that this gene is still expressed after prolonged tumor development. The loss of $\mathrm{Cx} 43$ expression in luteinized follicles may be due to persistently high $\mathrm{LH}$, as this hormone has been shown to downregulate the expression of $\mathrm{Cx} 43$ $(42,43)$ and luteinized tissue is more responsive to LH than to FSH. Therefore, although corpora lutea do not degenerate in this tumor (see above), they seem to lose some of the traits of active luteal tissue. In this regard, we have previously shown that luteoma cells secrete less progesterone and more estradiol than other highly luteinized cells (5).

StAR protein is the hormone-stimulated factor responsible for transfer of cholesterol from cellular stores to the inner mitochondrial membrane and is thus the true rate-limiting step in steroidogenesis; its activation by gonadotropins is critical for progesterone production by the corpus luteum $(19,45)$. In rats bearing intrasplenic ovarian autotransplants, peripheral steroid levels are not elevated, due to shunt of blood flow to the liver, where they are metabolized (3). However, active steroidogenesis is indicated by high StAR protein expression, in agreement with progesterone and estradiol secretion into the splenic vein, which collects tumor output (3). StAR was demonstrated only in luteinized follicles and in thecal cells, but was absent from granulosa cells of follicles, indicating that the latter do not participate in de novo steroid production, in agreement with previous data $(24,46)$. The presence of StAR mRNA was confirmed by RT-PCR in luteoma of 1,3 and 7 months of development, suggesting active steroidogenesis even in late stages of tumor development and that the expression of this protein is probably maintained by high persistent gonadotropin levels present in these animals.

The key enzyme catalyzing the last step of estradiol biosynthesis in the ovary is $\mathrm{P}_{450}$ aromatase. Its expression and regulation in rat granulosa cells has been found to be associated with follicular development and luteinization $(47,48)$ and this enzyme is also frequently present in benign and malignant ovarian tumors (49). In luteoma, aromatase expression was very intense in granulosa cells and was also present in luteal cells, in agreement with high estradiol output by tumor cells (5). As with other factors described above, we suggest that high gonadotropins maintain aromatase expression in luteoma cells, in agreement with that which has been described in the normal ovary $(50,51)$.

The synaptosome-associated $25 \mathrm{kDa}$ protein was initially described in the nervous system (52) and it was demonstrated to be involved in regulated exocytosis (53). Grosse et al. (17) recently demonstrated its expression in non-neuronal, non-neuroendocrine compartments of the ovary, specifically in steroidproducing cells such as follicular and luteal cells, as well as in oocytes. Ovarian cells, in addition to steroids, also synthesize many other products, including peptides, growth factors and hormones, which are secreted by regulated exocytosis, and this process may involve SNAP-25. In luteoma sections, we determined membrane-associated and cytoplasmic SNAP-25 immunostaining in patches of endocrine cells in follicles, as well as in luteinized follicles, in agreement with our previous observations (17). It is noteworthy that neither SNAP-25 nor TH-immunoreactive nerve fibers were found in the transplants (but were present in the spleen), indicating that, after transplantation into the spleen, the ovaries do not became readily re-innervated. Elevated FSH in luteoma-bearing animals may be involved in the regulation of SNAP-25 expression in luteoma cells, as was demonstrated in the GFSHR17 granulosa cell line (17). In addition, the presence of SNAP-25 mRNA was confirmed by RT-PCR during tumor development.

Inhibin has been postulated as a marker of ovarian tumors $(13,14)$ and the synthesis of inhibin subunits was demonstrated in these tumors from early to late stages of development, coinciding with SNAP-25 expression, suggesting that these may be related events, although the co-expression of both proteins in the same cells remains to be demonstrated.

In conclusion, various immunocytochemical parameters, described in the normal ovary, were detected in the intrasplenic ovarian tumor. Gonadotropins probably play a fundamental role inducing tumor growth and in maintaining the expression of characteristic proteins, even after 7 months of development, while avoiding apoptosis at the same time. The results obtained indicate that luteomas most likely develop from unruptured follicles by hypertrophy and proliferation of follicular cells and that they represent a highly differentiated non-metastatic tumor model, in which many traits normally observed in the ovary are conserved.

\section{Acknowledgements}

This work was supported by grants from Consejo Nacional de Investigaciones Científicas y Técnicas (CONICET), Agencia Nacional de Promoción Científica y Tecnológica (ANPCyT; BID 802 OC AR PICT 0043), 
Universidad de Buenos Aires, Ministerio de Salud de la Nación, Argentina and VolkswagenStiftung and Deutsche Forschungsgemeinschaft, Germany. We thank B Zschiesche and M Rauchfuss for technical help.

\section{References}

1 Biskind M \& Biskind G. Development of tumors in the rat ovary after transplantation into the spleen. Proceedings of the Society for Experimental Biology and Medicine 194455 176-179.

2 Lux VAR, Tesone M, Larrea GA \& Libertun C. High correlation between prolactinemia, 125-I hLH binding and progesterone secretion by an experimental luteoma. Life Sciences 198435 $2345-2352$.

3 Lux-Lantos VAR, Thyssen SM, Chamson-Reig A \& Libertun C. Effect of a gonadotropin releasing hormone analog on an experimental ovarian tumor: direct and indirect actions. Life Sciences $199557291-300$.

4 Chamson-Reig A, Bianchi MS, Rey-Roldán EB, Sorianello E, Libertun C \& Lux-Lantos VA. Development of an experimental ovarian tumor over a year in the rat. Life Sciences 199965 1275-1285.

5 Chamson-Reig A, Lux-Lantos VAR, Tesone M \& Libertun C. GnRH receptors and GnRH endocrine effects on luteoma cells. Endocrine $19976165-171$.

6 Chamson-Reig A, Pignataro OP, Libertun C \& Lux-Lantos V. Alterations in intracellular messengers mobilized by gonadotropin-releasing hormone in an experimental ovarian tumor. Endocrinology 1999148 3573-3580.

7 Auersperg N, Edelson MI, Mok SC, Johnson SW \& Hamilton TC. The biology of ovarian cancer. Seminars in Oncology 199825 281-304.

8 Wise PM. Neuroendocrine correlates of aging. In Neuroendocrinology in Physiology and Medicine, edn 21, pp 371-387. Eds PM Conn \& ME Freeman. Totowa N.J.: Humana Press, 2000.

9 Schally AV. Luteinizing hormone-releasing hormone analogs: their impact on the control of tumorigenesis. Peptides 199920 $1247-1262$

10 Emons G \& Schultz KD. Primary and salvage therapy with LH-RH analogues in ovarian cancer. Recent Results in Cancer Research $200015383-94$.

11 Willemsen W, Kruitwagen R, Bastiaans B, Hanselaar T \& Rolland R. Ovarian stimulation and granulosa-cell tumour. Lancet 1993 341 986-988.

12 Barontini M, Garcia-Rudaz MC \& Veldhuis JD. Mechanisms of hypothalamic-pituitary-gonadal disruption in polycystic ovarian syndrome. Archives of Medical Research 200132 544-552.

13 Cooke I, O'Brien M, Charnock FM, Groome N \& Ganesan TS. Inhibin as a marker for ovarian cancer. British Journal of Cancer 199571 1046-1050.

14 Risbridger GP, Schmitt JF \& Robertson DM. Activins and inhibins in endocrine and other tumors. Endocrine Reviews 200122 $836-858$.

15 Mayerhofer A \& Garfield RE. Immunocytochemical analysis of the expression of gap junction protein 43 in the rat ovary. Molecular Reproduction and Development 199541 331-338.

16 Sommersberg B, Bulling A, Salzer U, Fröhlich U, Garfield RE, Amsterdam A et al. Gap junction communication and connexin 43 gene expression in rat granulosa cells: regulation by FSH. Biology of Reproduction 200063 1661-1668.

17 Grosse J, Bulling A, Brucker C, Berg U, Amsterdam A, Mayerhofer A et al. Synaptosome associated protein of $25 \mathrm{kDA}$ (SNAP-25) in oocytes and steroid producing cells of the rat and human ovary: molecular analysis and regulation by gonadotrophins. Biology of Reproduction 200063 643-650.

18 Fritz S, Wessler I, Breitling R, Rossmanith WG, Ojeda SR, Dissen GA et al. Expression of muscarinic receptor types in the primate ovary and evidence for nonneuronal acetylcholine synthesis. Journal of Clinical Endocrinology and Metabolism 200186 349354.

19 Fritz S, Grünert RA, Stocco DM, Hales DB \& Mayerhofer A. StAR protein is increased by muscarinic receptor activation in human luteinized granulosa cells. Molecular and Cellular Endocrinology $200117149-51$.

20 Billig H, Furuta I \& Hsueh AJW. Gonadotropin-releasing hormone directly induces apoptotic cell death in the rat ovary: biochemical and in situ detection of deoxyribonucleic acid fragmentation in granulosa cells. Endocrinology 1994134 245-252.

21 Beyer C, Gree SJ, Barker PJ, Huskinsson NS \& Hutchinson JB. Aromatase-immunoreactivity is localised specifically in neurons in the developing hypothalamus and cortex. Brain Research $1994638203-210$

22 Chomczynski P \& Sacchi N. Single-step method of RNA isolation by acid guanidinium thiocyanate-phenol-chloroform extraction. Analytical Biochemistry $1987162156-159$.

23 Clark BJ, Wells J, King SR \& Stocco DM. The purification, cloning and expression of a novel LH-induced mitochondrial protein in MA-10 mouse Leydig tumor cells: characterization of the steroidogenic acute regulatory protein (StAR). Journal of Biological Chemistry $199426928314-28322$.

24 Ronen-Fuhrmann T, Timberg R, King SR, Hales KH, Hales DB, Stocco DM et al. Spatio-temporal expression patterns of steroidogenic acute regulatory protein (StAR) during follicular development in the rat ovary. Endocrinology 1998139 303-315.

25 Woodruff TK, Ackland J, Rahal JO, Schwartz NB \& Mayo KE. Expression of ovarian inhibin during pregnancy in the rat. Endocrinology 1991128 1647-1654.

26 Somers JP, Benyo DF, Little-Ihrig L \& Zeleznik AJ. Luteinization in primates is accompanied by loss of a 43-kilodalton adenosine $3^{\prime}, 5^{\prime}$-monophosphate response element-binding protein isoform. Endocrinology $19951364762-4768$.

27 Fricke PM, al-Hassan MJ, Roberts AJ, Reynolds LP, Redmer DA \& Ford JJ. Effect of gonadotropin treatment on size, number, and cell proliferation of antral follicles in cows. Domestic Animal Endocrinology 199714 171-180.

28 Piontkewitz Y, Sundfeldt K \& Hedin L. The expression of c-myc during follicular growth and luteal formation in the rat ovary in vivo. Journal of Endocrinology 1997152 395-406.

29 Makarevich A, Sirotkin A, Chrenek P, Bulla J \& Hetenyi L. The role of IGF-1, cAMP/protein kinase A and MAP-kinase in the control of steroid secretion, cyclic nucleotide production, granulosa cell proliferation and preimplantation embryo development in rabbits. Journal of Steroid Biochemistry and Molecular Biology 200073 123-133.

30 Louhio H, Hovatta O, Sjoberg J \& Tuuri T. The effects of insulin, and insulin-like growth factors I and II on human ovarian follicles in long-term culture. Molecular Human Reproduction 20016 694-698.

31 Lund SA, Murdoch J. Van Kirk EA \& Murdoch WJ. Mitogenic and antioxidant mechanisms of estradiol action in preovulatory ovine follicles: relevance to luteal function. Biology of Reproduction 1999 $61388-392$.

32 Hockl P, Sorianello E, Chamson-Reig A, Campo S, Groome N, Libertun $\mathrm{C}$ et al. Inhibins and FSH in the early development of an experimental ovarian tumor. International Workshop on: Inhibins, Activins and Follistatins. The Ares-Serono Foundation, Abstract pp 60. Monash Medical Centre, Melbourne, Victoria, Australia, 2000.

33 Schonborn I, Minguillon C, Reles A, Bartel U \& Lichtenegger W. Significance of PCNA proliferating fraction for prognosis of ovarian carcinoma. Geburtshilfe und Frauenheilkunde 199656 $357-364$.

34 Dharmarajan AM, Hisheh S, Singh B, Parkinson S, Tilly KI \& Tilly JL. Antioxidants mimic the ability of chorionic gonadotropin to suppress apoptosis in the rabbit corpus luteum in vitro: a novel role for superoxide dismutase in regulating bax expression. Endocrinology 1999140 2555-2561. 
35 Chun S-Y, Billig H, Tilly JL, Furuta I, Tsafriri A \& Hsueh AJW. Gonadotropin suppression of apoptosis in cultured preovulatory follicles: mediatory role of endogenous insulin-like growth factor I. Endocrinology 1994135 1845-1853.

36 Leo CP, Hsu SY, Chun S-Y, Bae H-W \& Hsueh AJW. Characterization of the antiapoptotic Bcl-2 family member myeloid cell leukemia-1 (Mcl-1) and the stimulation of its message by gonadotropins in the rat ovary. Endocrinology $19991405469-5477$.

37 Kumar T, Wang Y \& Matzuk M. Gonadotropins are essential modifier factors for gonadal tumor development in inhibin-deficient mice. Endocrinology $19961374210-4216$.

38 Kumar TR, Palapattu G, Wang P, Woodruff TK, Boime I, Byrne MC et al. Transgenic models to study gonadotropin function: the role of follicle-stimulating hormone in gonadal growth and tumorigenesis. Molecular Endocrinology 199913 851-865.

39 Grazul-Bilska AT, Redmer DA, Bilski JJ, Jablonka-Shariff A, Doraiswamy V \& Reynolds LP. Gap junctional proteins, connexin 26, 32, and 43 in sheep ovaries throughout the estrous cycle. Endocrine 19988 269-279.

40 Beyer EC, Kistler J \& Goodenough DA. Antisera directed against connexin 43 peptides react with a $43-\mathrm{kD}$ protein localized to gap junctions in myocardium and other tissues. Journal of Cell Biology 1989108 595-605.

41 Risek B, Guthrie S, Kumar N \& Gilula NB. Modulation of gap junction transcript and protein expression during pregnancy in the rat. Journal of Cell Biology $1990110269-282$.

42 Granot I \& Dekel N. Cell-to-cell communication in the ovarian follicle: developmental and hormonal regulation of the expression of connexin43. Human Reproduction 199813 85-97.

43 Granot I \& Dekel N. Phosphorylation and expression of connexin43 ovarian gap junction protein are regulated by luteinizing hormone. Journal of Biological Chemistry $199426930502-30509$.

44 Umhauer S, Ruch RJ \& Fanning J. Gap junctional intercellular communication and connexin 43 expression in ovarian carcinoma. American Journal of Obstetrics and Gynecology 2000182 999-1000

45 Stocco DM. Star protein and the regulation of steroid hormone biosynthesis. Annual Review of Physiology 200163 193-213.

46 Bao B, Calder MD, Xie S, Smith MF, Salfen BE, Youngquist RS et al. Expression of steroidogenic acute regulatory protein messenger ribonucleic acid is limited to theca of healthy bovine follicles collected during recruitment, selection, and dominance of follicles of the first follicular wave. Biology of Reproduction $1998 \quad \mathbf{5 9}$ 953-959.

47 Richards JS, Hickey GJ, Chen S, Shively JE, Hall PF, Gaddy-Kurten $\mathrm{D}$ et al. Hormonal regulation of estradiol biosynthesis, aromatase activity and aromatase mRNA in rat ovarian follicles and corpora lutea. Steroids $1987 \mathbf{5 0} 393-409$.

48 el-Maasarany S, Brandt ME, Majercik MH, Zimniski SJ \& Puett D. Immunocytochemical localization and enzymatic distribution of rat ovarian aromatase. Biology of Reproduction $19914 \mathbf{4 5 5 0 -}$ 560.

49 Kitawaki J, Noguchi T, Yamamoto T, Yokota K, Maeda K, Urabe M et al. Immunohistochemical localisation of aromatase and its correlation with progesterone receptors in ovarian epithelial tumours. Anticancer Research 199616 91-98.

50 Gonzalez-Robaina IJ, Alliston TN, Buse P, Firestone GL \& Richards JS. Functional and subcellular changes in the A-kinase-signalling pathway: relation to aromatase and Sgk expression during the transition of granulosa cells to luteal cells. Molecular Endocrinology $1999131318-1337$.

51 Overes HW, de Leeuw R \& Kloosterboer HJ. Regulation of aromatase activity in FSH-primed rat granulosa cells in vitro by folliclestimulating hormone and various amounts of human chorionic gonadotrophin. Human Reproduction 19927 191-196.

52 Oyler GA, Higgins GA, Hart RA, Battenberg E, Billingsley M, Bloom FE et al. The identification of a novel synaptosomal-associated protein, SNAP-25, differentially expressed by neural subpopulations. Journal of Cell Biology 1989109 3039-3052.

53 Masumoto N, Ikebuchi Y, Matsuoka T, Tasaka K, Miyake A \& Murata Y. Involvement of SNAP-25 in TRH-induced exocytosis in pituitary GH4C1 cells. Journal of Endocrinology 1997153 $\mathrm{R} 5-\mathrm{R} 10$

Received 27 February 2002

Accepted 16 May 2002 